\title{
How Lean and Green Management Improve Denim Manufacturing Performances
}

\author{
Mohamed Jouhri \\ $\mathrm{Ph}$. D Student \\ Laboratory LASTIMI, CEDOC EMI \\ Rabat, Morocco
}

\author{
Aziz Soulhi \\ Professor \\ National Higher School of Mines, \\ Rabat, Morocco
}

\begin{abstract}
Denim has been and still is an important item of clothing for many decades, but the process to produce is still an extremely wasteful.

Leaders on this industry are out to change that by employing new processes that reduce water drastically and consumes less energy and chemicals in order to improve customers satisfaction.

Applying lean principles in a manufacturing facility can help improving product and practices. This lean thinking must be "green" in order to reduce wastes and to be eco-friendly

In this paper, I focus on strategy and tools used on the lean green management, on why and how we should combine lean and green in denim manufacturing process based on some researches realized in one of the biggest laundries in morocco NEW WASH.

From Measuring Visualizing and through other statistical results, I was able to conclude that sustainability/quality/supply chain/cost Performances can be improved by applying lean and green tools in this important industry.
\end{abstract}

Keywords-Green; Lean; Management; Quality; Cost; Process; Productivity; Environment; Sustainability; Impact; KPI

\section{INTRODUCTION}

The global Denim Industry is undergoing a very challenging period since 2004 where the traditional Quota systems for textile and clothing phased out.

Several structural changes have led to a new business environment based on high efficiency that all factories should adapt to.

Business efficiency is how much output a business produces for a unit of input. It is the opposite of waste. Efficiency measures how well a business converts inputs such as capital, labor and materials into outputs like revenue, products and services. The following are common types of business efficiency.

When we have the ideal business in our mind then we can look at our reality and see where the gaps are so we can work towards making the reality matching with our dream and our vision.

The future of denim is secure, and its popularity is ever growing throughout the world. Denim factories are facing the challenge of being ideal for their customers, they are looking towards management and strategies that can achieve these goals.
The areas of growth in this direction include: -Customized fashionable and trendy garment production on time with lower prices and best quality

-Environmental impact reduced taking all possible measures.

Because ecology and fast fashion will continue to be the driving factors for jeans production and marketing, the Ideal denim company should be customer-oriented and ecofriendly. Denim factories can improve their global performances by adopting Lean and Green Management.

\section{Overview of sustainability and Lean Management}

\section{A. Sustainability}

Ecological engagement consists of a series of continuous evaluations and energy consumption measures used in the process in order to eliminate the environmental wastes.

Environmental waste is any unnecessary use of resources or a substance released into the air, water, or land that could harm human health or the environment. These wastes are often a sign of inefficient production, and they frequently indicate opportunities for saving cost and time.

Reducing the use of energy, water, chemicals and other noisome materials in the apparel industry, reducing the environment impact of industries all over the world become now possible by building sustainable management and sustainable values with all company leaders.

\section{B. Lean Management}

The lean management is a conceptual framework based on a few established principles and techniques and a systematic approach to identifying and eliminating waste through continuous improvement of operational efficiency in such a way that the production activities will continuously meet customer expectations at the lowest possible cost through the interaction of the workers with the process.

Lean manufacturing tool mainly work to eliminate three types of waste:

- Muda: valueless work

- Mura: unevenness

- Muri: overburden 
Muda or the seven wastes consist of:

1- Transport: The movement of product between operations andlocations.

2- Inventory: The work in progress (WIP) and stocks of finished goods and raw materials that a company holds.

3- Motion: The physical movement of a person or machine while conducting an operation.

4- Waiting: The act of waiting of a machine or a person for something.

5- Over production: Over producing product beyond customers order.

6- Over processing: Conducting operations beyond customer requirements.

7- Defects: Product rejection and rework.

\section{GREEN LEAN MANAGEMENT}

The major inputs in the denim process production are water and chemical products. But since the process relays mainly on machinery we must also consider energy and time as two major parameters to interpret how can these consumptions impact the productivity. These parameters are often considered as significant manufacturing wastes in denim world.

The idea of combining Lean management with green goals can help reducing these wastes saving time energy for a good economic and environment impact

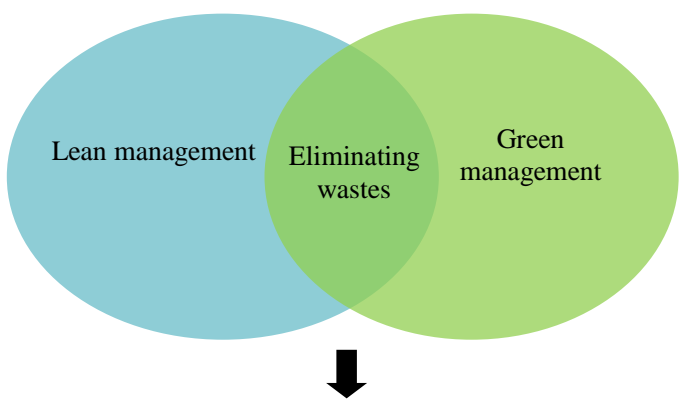

Economic profits

Better Environmental impact Eco-efficiency

Fig. 1. Combination of Lean and Green Management

The green management in denim world is made to eliminate as much as possible the waste of water consumption, of chemicals and time, while the lean concept is a systematic process for eliminating all kind of waste and improving operational efficiency such that the production activities will continuously meet customer expectations at the lowest possible cost through the interaction of the worker with the process. Merging those concepts is what we call the green lean management.
The paper provides evidence:

That lean is beneficial for green practices and the implementation of green practices in turn also has a positive influence on existing business practices.

- That the lean practices are synergistic for green and how green practices are synergistic for lean.

- There are opportunities for companies to use their lean framework as a catalyst to make their processes green.

\section{Our strategy and tools}

Through this step and tools, we can finally guarantee a better financial outcome that will focus more on making the least damage of the environment without grinding our production quality.

TABLE I. STEPS OF LEAN MANUFACTURING STARTEGY

\begin{tabular}{|c|c|}
\hline Steps & Tools \\
\hline Mapping the supply chain & VSM \\
\hline Picking up the right KPIs & Brainstorming, Ishikawa \\
\hline Evaluating the KPIs & $\begin{array}{c}\text { Timing, Platform EIM } \\
\text { (Environment impact } \\
\text { measurement), data reports.. }\end{array}$ \\
\hline $\begin{array}{c}\text { Analyzing the results \& } \\
\text { choosing the upper and lower } \\
\text { specification limits of the KPIs }\end{array}$ & \begin{tabular}{c} 
Benchmarking and measurement \\
\hline Developing a plan
\end{tabular} \\
\hline $\begin{array}{c}\text { Controlling the KPIs evaluations ( } \\
\text { measures ) }\end{array}$ & $\begin{array}{c}\text { Timing, Platform EIM , data } \\
\text { reports .. }\end{array}$ \\
\hline Standardizing & $\begin{array}{c}\text { Standardized work, Procedure, } \\
\text { Meeting, Training }\end{array}$ \\
\hline
\end{tabular}

Standardized work ${ }^{1}$ : this is a documented description of every process (with responsibility, how to do and estimated time). This procedure of manufacturing captures best practices.

$5 S^{2}$ : It eliminates waste that results from a poorly organized work area. See $5 \mathrm{~s}$ below:

- Sort: Remove unnecessary items.

- Set in Order: Organize remaining items.

- Shine: Clean and inspect work area.

- Standardize: Write standards for above.

- Sustain: Regularly apply the standards.

Kaizen (continuous Improvement) ${ }^{2}$ : the Japanese word 'Kaizen' simply means 'change for better'. Kaizen aims to eliminate wastes \& continuous improvement.

Many useful tools and techniques can be used to combine and apply the lean and green management.

The Value Stream Mapping was used in New Wash (Denim laundry) for illustrating and analyzing the logic of the washing process. Determining the value stream to be improved, understanding how things currently operate is the foundation for the future New Wash redesigning process according to lean and green management. 
VSM of NEW WASH in June 2018:

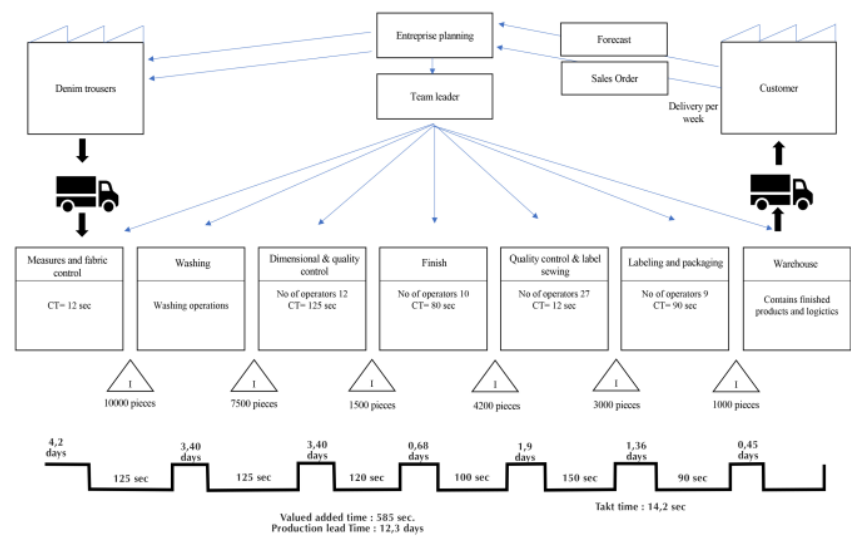

Fig. 2. New Wash VSM

The Single Minute Exchange of Die is an organization method that seeks to systematically reduce the time series change with a quantified goal. This system is based on changing over the operations as much as possible and to simplify and streamline the remaining operation in order to perform the productivity while the equipment is running.

Taking into considerations the environmental impact in the SMED method can be practically done with the EIM scoring of Jeanologia's platform (known machines supplier) before and after eliminating wastes of water, energy, time, chemicals.

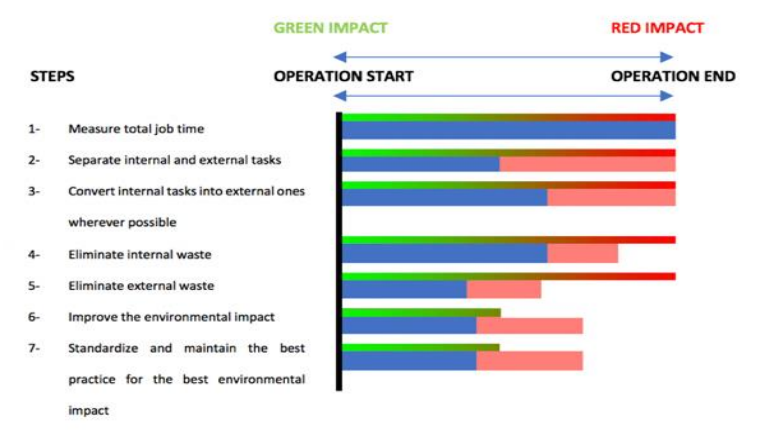

Fig. 3. Green SMED steps

\section{PICKING UP THE RIGHT KPIs FOR NEW WASH MANAGERS}

'With no measurement there's no improvement' is the slogan of the company.

How can we choose the right KPIs?

We choose the KPIs that are aligned with our goals

We don't attempt to measure everything

We use qualitative and quantitative KPIs

We follow the trend as it's updated.

\section{A. Is the factory Lean enough?}

Having that tactical picture that will provide us how to start our LEAN improvement is the most important step in lean management. The following table shows the main Lean KPIs used in NEW WASH.

TABLE II. LEAN MANUFACTURING KPI'S USED IN NW

\begin{tabular}{|c|c|c|}
\hline & \multicolumn{2}{|c|}{ LEAN KPIs } \\
\hline & Quality & Production downtime \\
\hline Measurement & $\begin{array}{l}\text { good count / total count } \\
\text { X } 100 \\
\text { (Total count }- \text { reject } \\
\text { count }=\text { good count })\end{array}$ & $\begin{array}{l}\text { run time / planned } \\
\text { production time X } 100 \\
\text { (Planned production } \\
\text { time }- \text { stop time = run } \\
\text { time). } \\
\text { (Shift time - break time } \\
\text { = planned production } \\
\text { time) }\end{array}$ \\
\hline KPI & Quality pourcentage & Avaibility pourcentage \\
\hline $\begin{array}{l}\text { Improvement's } \\
\text { tools }\end{array}$ & $\begin{array}{l}\text { In this process, each } \\
\text { operator checks his / } \\
\text { her own work before } \\
\text { the part or product is } \\
\text { sent to the next step in } \\
\text { the process. }\end{array}$ & Timing \\
\hline
\end{tabular}

TABLE III. LEAN MANUFACTURING KPI'S USED IN NW

\begin{tabular}{|c|c|c|c|}
\cline { 2 - 4 } \multicolumn{1}{c|}{} & \multicolumn{3}{c|}{ LEAN KPIs } \\
\cline { 2 - 4 } & $\begin{array}{c}\text { Production } \\
\text { capacity }\end{array}$ & Performance & $\begin{array}{c}\text { Delayed } \\
\text { delivery }\end{array}$ \\
\hline \multirow{2}{*}{ Measurement } & $\begin{array}{c}\text { Daily } \\
\text { production } \\
\text { deliveries }- \\
\text { Total } \\
\text { delayed } \\
\text { deliveries/ } \\
\text { Total } \\
\text { KPI }\end{array}$ & $\begin{array}{c}\text { (ideal cycle } \\
\text { time X total } \\
\text { count / run } \\
\text { time X 100 } \\
100\end{array}$ \\
\hline $\begin{array}{c}\text { Improvement's } \\
\text { tools }\end{array}$ & $\begin{array}{c}\text { Benchmarking } \\
\text { Reports }\end{array}$ & Sumber of \\
garments / day & Performance & $\begin{array}{c}\text { Pourcentage } \\
\text { of delayed } \\
\text { deliveries } \\
\text { per semester }\end{array}$ \\
\hline
\end{tabular}

B. Is the factory Green enough ?

As environmental impact relies on natural sources consumption, reducing the environmental impact begin with consumption measures used in every process.

As shown down, we present the KPIs in denim world developed with some partners to measure the environmental impact.

TABLE IV. GREEN ENVIRONMENTAL KPI'S USED IN NW

\begin{tabular}{|c|c|c|c|}
\cline { 2 - 4 } \multicolumn{1}{c|}{} & \multicolumn{3}{c|}{ GREEN KPIs } \\
\cline { 2 - 4 } \multicolumn{1}{c|}{} & Water impact & Energy impact & $\begin{array}{c}\text { Chemicals } \\
\text { impact }\end{array}$ \\
\hline KPI & $\begin{array}{c}\text { Water } \\
\text { consumption } \\
\text { 1/garment }\end{array}$ & $\begin{array}{c}\text { Energy } \\
\text { consumption } \\
\text { KWh/garment }\end{array}$ & 1/garment \\
\hline Measurement & $\begin{array}{c}\text { Jeanologia } \\
\text { platform }\end{array}$ & $\begin{array}{c}\text { Jeanologia } \\
\text { platform }\end{array}$ & $\begin{array}{c}\text { Jeanologia } \\
\text { platform }\end{array}$ \\
\hline Improvement & $\begin{array}{c}\text { Recipe } \\
\text { developpement } \\
+ \text { Water } \\
\text { treatment }\end{array}$ & $\begin{array}{c}\text { Recipe } \\
\text { developpement }\end{array}$ & $\begin{array}{c}\text { Recipe } \\
\text { developpement }\end{array}$ \\
\hline
\end{tabular}


TABLE V. GREEN ENVIRONMENTAL KPI'S USED IN NW

\begin{tabular}{|c|c|c|c|c|}
\cline { 2 - 5 } \multicolumn{1}{c|}{} & Timing & Materiel & $\begin{array}{c}\text { Worker } \\
\text { health }\end{array}$ & $\begin{array}{c}\text { EIM } \\
\text { scoring }\end{array}$ \\
\hline KPI & $\begin{array}{c}\text { Min/garm } \\
\text { ent }\end{array}$ & $\begin{array}{c}\text { Number or } \\
\mathrm{kg} / \text { garment }\end{array}$ & Score & $\begin{array}{c}\text { Environmen } \\
\text { tal impact of } \\
\text { product }\end{array}$ \\
\hline $\begin{array}{c}\text { Measurem } \\
\text { ent }\end{array}$ & $\begin{array}{c}\text { Jeanologi } \\
\text { a platform }\end{array}$ & $\begin{array}{c}\text { Jeanologia } \\
\text { platform }\end{array}$ & $\begin{array}{c}\text { Jeanologia } \\
\text { platform }\end{array}$ & $\begin{array}{c}\text { Jeanologia } \\
\text { platform }\end{array}$ \\
\hline $\begin{array}{c}\text { Improvem } \\
\text { ent }\end{array}$ & SMED & $\begin{array}{c}\text { Recipe } \\
\text { developpem } \\
\text { ent }\end{array}$ & $\begin{array}{c}\text { Recipe } \\
\text { developpe } \\
\text { ment }\end{array}$ & $\begin{array}{c}\text { Recipe } \\
\text { developpem } \\
\text { ent }\end{array}$ \\
\hline
\end{tabular}

\section{Visualising}

Evaluating a countermeasure or a KPI for industry, is a provision taken to oppose an action, an effect, an event, or to prevent them.

A lazy analyst can then conclude that the countermeasure with the best overall average is the preferred solution. This intellectual laziness may be the best choice on many occasions, but it can happen that this type of thinking can lead to a disaster. Why? If the average result is good this doesn't mean that the global result is also good.

In this section, we are going to calculate the capability of water quantity that NEW WASH consumed and the percentage of $2^{\text {nd }}$ choice changed from Mars 2018 to October 2018.

The capability of a production process can be defined as the suitability of a machine or process to achieve a requested performance. It can be used to measure the capacity of a machine or a process to make parts within the tolerance range (defined by its lower and upper limits) mentioned in the specifications sheet.

$$
\begin{aligned}
& \mathrm{Cp}=\sqrt{\frac{U S L-L S L}{6 \sigma}} \\
& \mathrm{Cpk}=\operatorname{Min}\left(\frac{U S L-\text { Mean }}{3 \sigma} \cdot \frac{\text { Mean-LSL }}{3 \sigma}\right) .
\end{aligned}
$$

\section{Water Consumption Capabilities of NEW WASH}

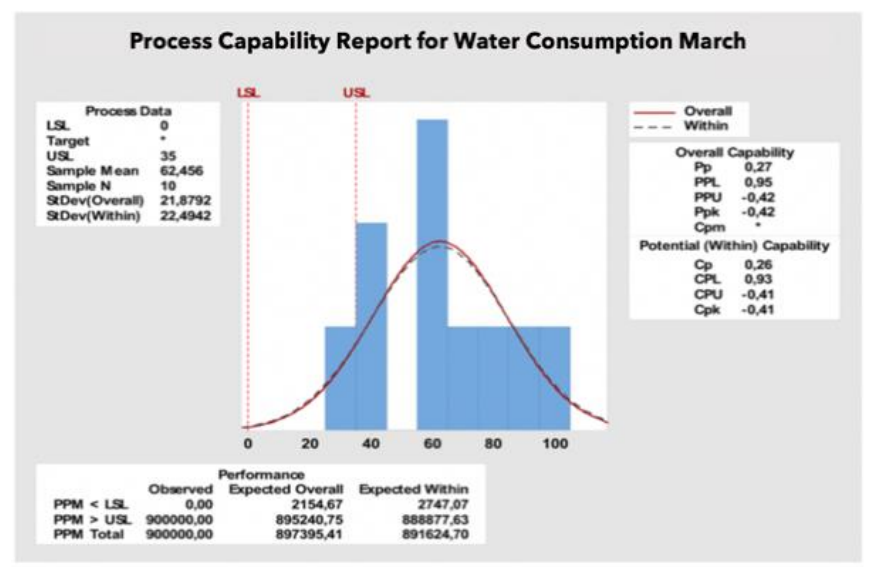

Fig. 4. Water Consumption Capability of March

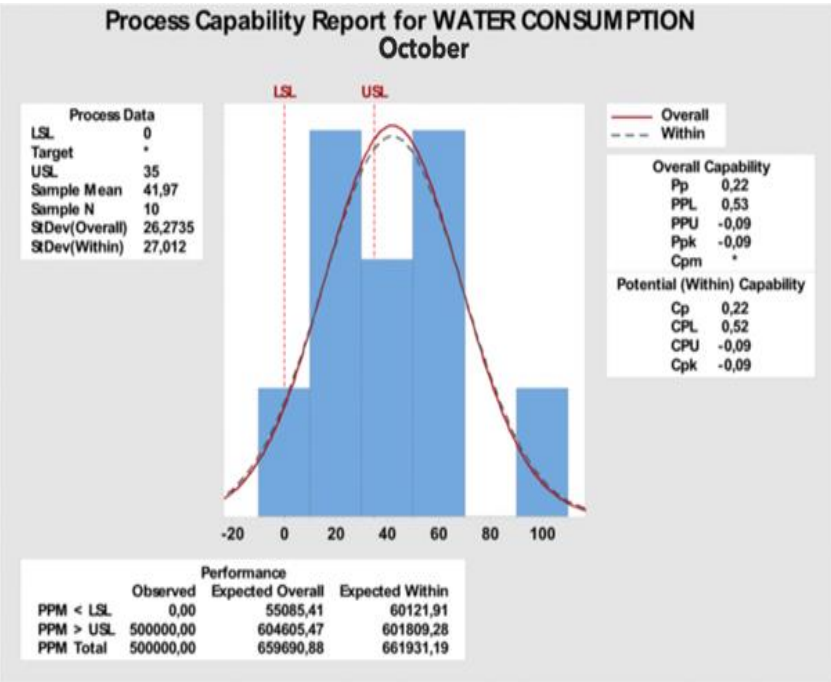

Fig. 5. Water Consumption Capability of October

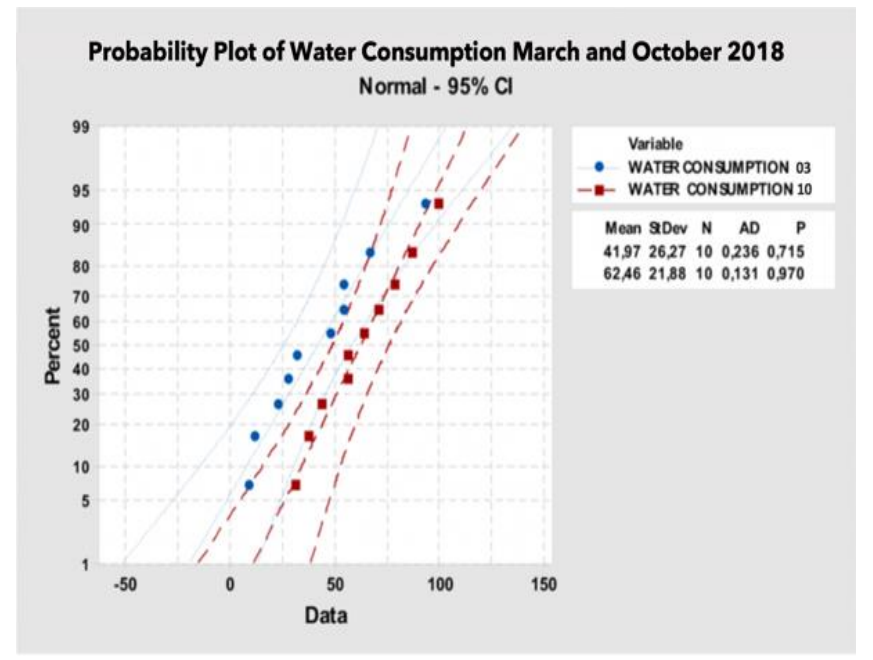

Fig. 6. Probability Plot of Water Consumption

\section{$2^{\text {nd }}$ choice Capabilities of NEW WASH}

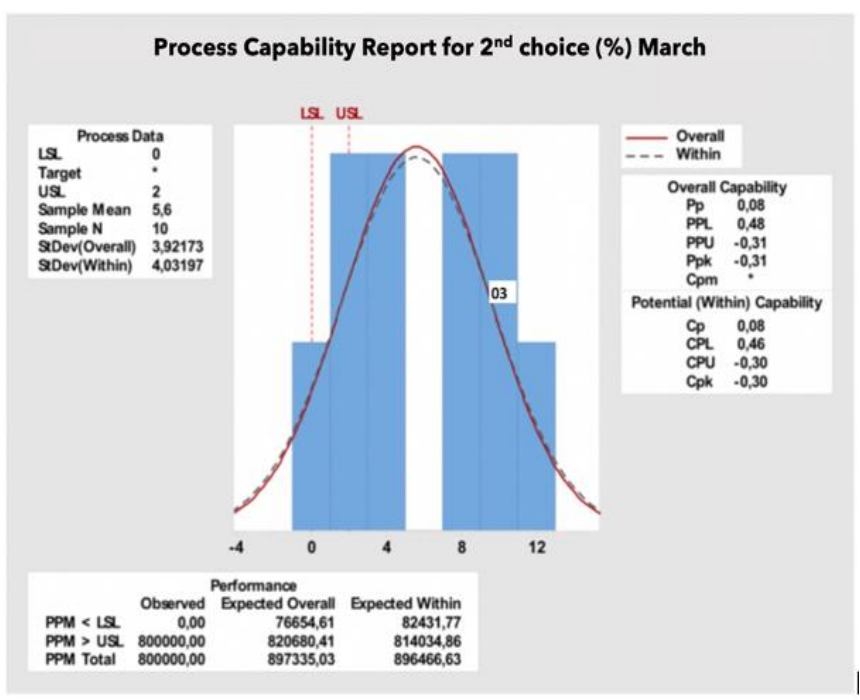

Fig. 7. $2^{\text {nd }}$ Choice Percentage Capability of March 


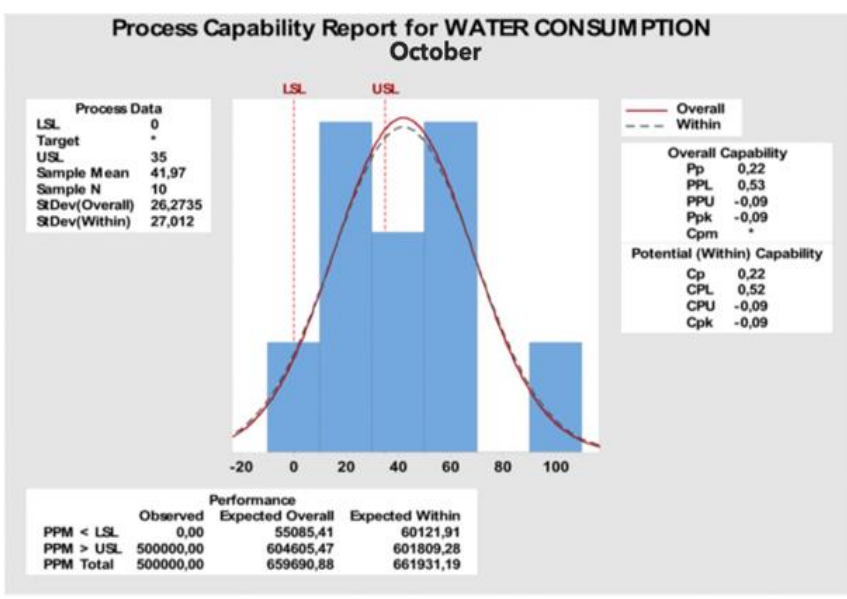

Fig. 8. $2^{\text {nd }}$ Choice Percentage Capability of October

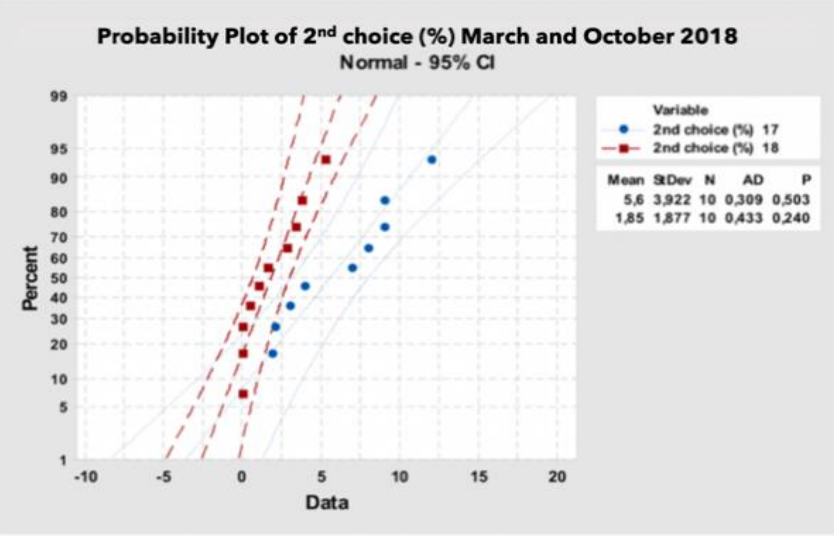

Fig. 9. Probability Plot of $2^{\text {nd }}$ Choice Percentage

\section{STATISTICAL RESULTS}

By implementing the above noted operational improvements, this facility have achieved the following results with providing an annual cost saving of $8 \%$ of our past yearly income.

- Reduction water consumption by over $32,8 \%$ using new technologies as the Ozone and the E-flow development of our the verticals partners of the facility.

- Reduction of energy consumption by $24,5 \%$ with the new recipe development.

- Increasing efficiency by $17,3 \%$.

Based on the 6 months of data provided in Mars, June and October, the full year water and energy consumption for this year could be almost half the consumption of the last year.

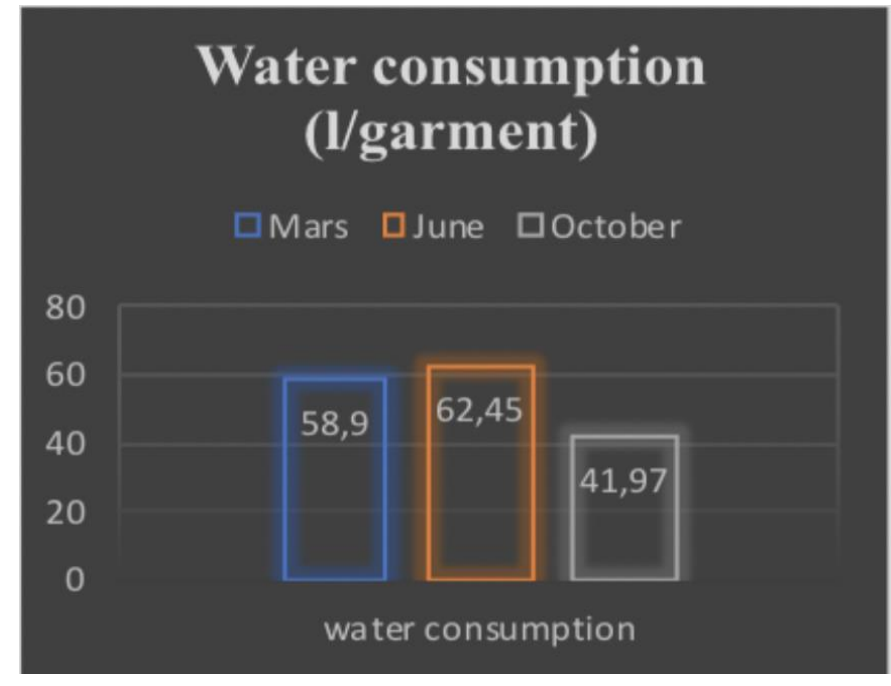

Fig. 10. Water consumption improvements

The following grape is a general summary of some lean manufacturing improvements. The notation was calculated through the KPIs as seen previously.

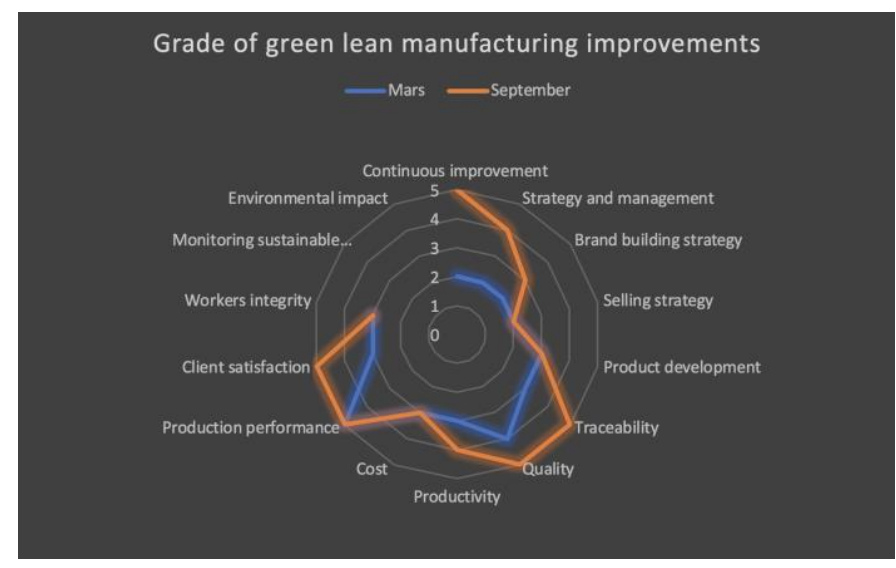

Fig. 11. Combination of Lean and Green Management

\section{CONCLUSION}

Eliminating waste, reducing costs, making production processes more reactive and sustainable makes all companies efficient and more attractive for their customers.

The global performances of the denim factories can be easily improved by applying lean and green management.

Through this paper we can understand that combining Kaizen attitude and sustainability will lead to quick wins and direct impact on KPI'S improvements.

Kaizen attitude and eco-friendly atmosphere can push all workers to do their jobs with quality and efficiency taking into account company profitability and customer satisfaction. 


\section{REFERENCES}

[1] Kainuma, Y., Tawara, N. (2006). A multiple attribute utility theory approach to lean and green supply chain management.

[2] Bicheno J., 2000. The Lean Toolbox, 2nd Edition. PICSIE Books, Buckingham, England.

[3] Bicheno J., 2004. The New Lean Toolbox: Towards Fast, Flexible Flow, 3rd ed., PICSIE Books, Buckingham.

[4] Black J.T. and Phillips D., 2010. The lean to green evolution. Industrial Engineer, June.
[5] Cabral I., Grilo A., Cruz-Machado V., 2012. A decision-making model for Lean, Agile, Resilient and Green supply chain management. International Journal of Production Research

[6] Friedman P., 2008. Leaning toward green : green your supply chain with lean practices - availableat: http://outsourcedlogistics.com/operations_strategy/leaning_toward_green. ${ }^{\circ}$

$$
1234567890
$$

[7] James P Womack and Daniel T.Jones . Lean Thinking. First edition.

[8] Philippe Lorino,2014. La fuite managériale devant la complexité : l'exemple historique du Lean Management. ESSEC business school, Paris, France. 